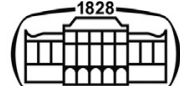

AKADÉMIAI KIADÓ

UNIVERSITY of DEBRECEN

International Review of Applied Sciences and Engineering

12 (2021) 2, 111-118

DOI:

$10.1556 / 1848.2020 .00157$

(c) 2020 The Author(s)

ORIGINAL RESEARCH PAPER

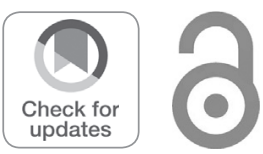

\section{An investigation on the performance and emission studies on diesel engine by addition of nanoparticles and antioxidants as additives in biodiesel blends}

\author{
Siddavatam Naresh Kumar Reddy* $\odot$ and Mohmad Marouf Wani
}

Department of Mechanical Engineering, National Institute of Technology, Srinagar, Jammu and Kashmir, India

Received: July 19, 2020 • Accepted: November 10, 2020

Published online: March 17, 2021

\section{ABSTRACT}

The study aims to examine the effects of palm biodiesel blended with additives in the compression ignition (CI) engine. Biodiesel as fuel was limited by challenges such as lower calorific value (CV) and higher viscosity while increasing brake specific fuel consumption (BSFC) and nitrogen oxides $\left(\mathrm{NO}_{\mathrm{x}}\right)$ emissions. Nanoparticles and antioxidant additives added to biodiesel play an essential role in avoiding the hindrances of biodiesel. The antioxidants combined with biodiesel reduced $\mathrm{NO}_{\mathrm{x}}$ emissions by eliminating decomposing peroxides, free radicals, and preventing free radicals' chain reaction. The Significant characteristics of nanoparticles are high CV, high thermal conductivity, and higher surface to volume ratio. These characteristics are used to improve the $\mathrm{CI}$ engine's performance and emissions by using nanoparticles blended with biodiesel. Five different test blends of Diesel, B20, B20TO, B20AO, and B20AOTO were prepared. The result showed high brake thermal efficiency (BTHE) and decreased BSFC, exhaust gas temperature (EGT), hydrocarbons ( $\mathrm{HC}$ ), $\mathrm{NO}_{\mathrm{x}}$, and $\mathrm{HC}$ emissions by using the B20AOTO fuel blend contrasted with other biodiesel blends.

\section{KEYWORDS}

palm biodiesel, titanium oxide, antioxidant NPPD, efficiency, emissions

\section{INTRODUCTION}

Fossil fuels have a vital role in the evolution of industrial growth, transport sector, agriculture, and many individual needs. The reserves of petroleum fuel decrease every day in the world. Thus, most of the researchers are looking for alternative fuels. Renewable fuels are more attractive to the reserves of fossil fuels. These are facing many challenges, including environmental issues, feedstock, product commercialization, waste glycerol glut problem, and society's acceptance. Biodiesel will be used as a substitute for diesel to face present and future energy demand. Biodiesel is produced from edible and non-edible oils, which are ecofriendly, reliable, non-toxic, and biodegradable. Biodiesel emits low carbon and smoke emissions compared to diesel, which reduces global warming. Biodiesel has a higher density, pour point, viscosity, and molecular weight than diesel. Major biodiesel problems were low fuel atomization, low volatility, injector coking, and piston ring trapping, leading to incomplete combustion due to its viscosity and molecular weight. Biodiesel comprises a long chain of fatty acids containing 10-14 percent oxygen by weight and does not contain sulfur and aromatics. Because of this reason, biodiesel is essential for enhancing complete combustion, decreasing $\mathrm{PM}, \mathrm{CO}, \mathrm{HC}$, but increasing nitrogen oxide $\left(\mathrm{NO}_{\mathrm{x}}\right)$ emissions when contrasted with diesel. In comparison, it has a lower calorific value (CV) when contrasted with diesel [1-9]. 
According to Mahmud et al. [10], palm oil is a potential biofuel source to be used as a fuel in compression ignition (CI) engine. It is the most efficient oil-bearing crop in efficiency, productivity, availability, and land utilization. It produces a higher yield than all other vegetable oils, so it is available at a competitive price. Because of these parameters, palm biodiesel as fuel has been selected in the current research work. The major biodiesel issues were low heating value, low oxidation stability, high brake specific fuel consumption (BSFC), and high $\mathrm{NO}_{\mathrm{x}}$ emissions compared to diesel; to avoid these problems different additives were used. Nano-additives consist of high surface to volume ratio, high calorific value, and high thermal conductivity, So it enhances the performance and emissions of diesel engines. Antioxidant additives in biodiesel effectively reduce the free radicals formation and improve the oxidation stability of the fuel. The $\mathrm{TiO}_{2}$ nano-additive is eco-friendly, low cost, and nontoxic compared to other nano-additives found in the literature. From the literature review, N-phenyl-1,4-phenylenediamine (NPPD) antioxidant additive appears to effectively reduce the $\mathrm{NO}_{\mathrm{x}}$ emissions and enhance the diesel engine's performance compared to other antioxidants.

\subsection{Literature review}

This section discusses the many works that have reported the effects on a diesel engine operated with using biodiesel, and blended with additives as fuels. Hirkude et al. [11] investigated the influence of waste fried biodiesel in DI CI engine. The results reported that the B50 biodiesel blend has a low CV value, increasing the $6.89 \%$ brake BSFC and $6.5 \%$ brake thermal efficiency (BTHE) reduced because of the low volatility of biodiesel. The $21-45 \%$ of CO, $23-47 \%$ of PM, and $50-100 \%$ of $\mathrm{SO}_{2}$ emissions reduced and increased $\mathrm{NO}_{\mathrm{x}}$ emissions due to advance injection process and complete combustion of biodiesel. Hasib et al. [12] conducted experiments on the CI engine using mustard biodiesel. The obtained results showed that biodiesel's BSFC increased because of low $\mathrm{CV}$ value, and the exhaust gas temperature (EGT) of all blends increased except for B30 blend compared with diesel.

Suleyman et al. [13] studied the effects on CI engine by using canola oil, waste oil, and sefflower oil biodiesels. The results reported CO emissions decreased by $34.28 \%$, hydrocarbons (HC) emissions by $17.49 \%$, and smoke emissions by $50.95 \%$, and $\mathrm{NO}_{\mathrm{x}}$ emissions increased by $80.5 \%$ and $\mathrm{CO}_{2}$ emissions by $42.62 \%$ with the use of different biodiesels contrasted with diesel. Rahman et al. [14] investigated the effects of CI engine by using palm and jatropha biodiesels. The results showed decreased CO emissions by $23.5-29 \%$ and $11.8-17.74 \%$, HC emissions by $34.5-39 \%$, and $31-35 \%$ and increased BSFC by $7.1-8.35 \%$ and by $8.83-9.29 \%, \mathrm{NO}_{\mathrm{x}}$ emissions by $22-25 \%$ and $17-18 \%$, respectively, for $\mathrm{B} 20$ blends of palm and jatropha biodiesel contrasted with diesel. Previous studies reported that biodiesel's significant issues were low heating value, low oxidation stability, high BSFC, and high $\mathrm{NO}_{\mathrm{x}}$ emissions compared to diesel; to avoid these problems different additives were used. Some reviewers reported that biodiesel blended with additives resulted improved performance and reduced emissions on CI engine. Nano-additives consist of high surface to volume ratio, high $\mathrm{CV}$, and high thermal conductivity, So, they enhance the performance and emissions of diesel engines. The antioxidants blended with biodiesel showed a more significant reduction of $\mathrm{NO}_{\mathrm{x}}$ emissions by decomposing peroxides, eliminating free radicals, and preventing free radicals' chain reaction.

Basha et al. [15] investigated the diesel engine with constant speed using jatropha biodiesel with aluminum and carbon nanotubes nanoparticles. The results reported that high BTHE by use of JBD25A25CNT blend compared with other blends because these nanoparticles increased the $\mathrm{CV}$ of biodiesel blends and lowered ignition delay of combustion. The emission results of the JBD25A25CNT blend showed decreased $\mathrm{NO}_{\mathrm{x}}$ and smoke opacity emissions with a high percentage and reduced $\mathrm{CO}$ and $\mathrm{HC}$ emissions when contrasted with diesel. Pawar et al. [16] investigated the effects of CI engine by blended graphene nanoparticles with HOME. The results reported that high BTHE by use of HOME50GRAPHENE blend compared with other blends because these nanoparticles increased the $\mathrm{CV}$ of biodiesel fuel and lowered ignition delay of combustion. The emissions results revealed reduced $\mathrm{HC}$, smoke opacity, $\mathrm{NO}_{\mathrm{x}}$, and $\mathrm{CO}$ emissions when using the HOME50GRAPHENE fuel blend instead of other blends.

Praveena et al. [17] examined the effects of performance and emission parameters on CI engine using zinc oxide nanoemulsion with biodiesel. The results reported that the BTHE increased slightly and reduced $10.8 \%$ of $\mathrm{NO}_{\mathrm{x}}, 13 \%$ of $\mathrm{HC}$, and $4.6 \%$ of $\mathrm{CO}$ emissions with GSBD $\mathrm{ZnO} 100$ blend as correlated to grapeseed oil methyl ester (GSBD). El-Seesy et al. [18] conducted the effects of CI engine by blended $\mathrm{Al}_{2} \mathrm{O}_{3}$ nanoparticles with jojoba biodiesel. The obtained biodiesel results with nanoparticle fuel blend showed reduced $\mathrm{BSFC}$ by $12 \%, \mathrm{NO}_{\mathrm{x}}$ by $70 \%$, $\mathrm{HC}$ by $60 \%$, smoke opacity by $35 \%$, and CO by $80 \%$ as contrasted to biodiesel. Dhana Raju et al. [19] studied the effects of $\mathrm{Al}_{2} \mathrm{O}_{3}$ nanoparticles blended with tamarind seed methyl ester as fuel on $\mathrm{CI}$ engine. The obtained results revealed increased BTHE by $1.6 \%$ and reduced $\mathrm{CO}$ by $15-51 \%, \mathrm{HC}$ by $24-68 \%$, and $\mathrm{NO}_{\mathrm{x}}$ by $7-9 \%$ by using biodiesel with an additive compared to biodiesel.

Musthafa et al. [20] conducted the experiments on CI engine by using DTBP antioxidants with biodiesel. The results reported decreased BSFC by $15 \%$, and increased BTHE by $3.5 \%$ by using biodiesel with an additive compared to the B20 fuel blend. $\mathrm{NO}_{\mathrm{x}}$ emissions decreased by $13-15 \%$ and reduced $\mathrm{CO}$ emissions but slightly increased $\mathrm{HC}$ emissions resulted by using biodiesel with an additive compared to the B20 fuel blend. Rajendran [21] conducted the effects of CI engine by annona biodiesel blended with phenylenediamine (PPDA) antioxidant additive fuel blend. The results showed that biodiesel with additive decreased up to $25.4 \%$ of $\mathrm{NO}_{\mathrm{x}}$ emissions contrasted with diesel. Dueso et al. [22] carried out the experiments on CI engine by antioxidant additive from bio-oil blended with sunflower biodiesel. The results 
showed that biodiesel with additive reduced smoke opacity and $\mathrm{NO}_{\mathrm{x}}$ by $4.4 \%$ and $3 \%$, respectively, but it increased $\mathrm{HC}$ and $\mathrm{CO}$ by $14.3 \%$ and $0.7 \%$, respectively, as contrasted with biodiesel. Ashok et al. [23] studied the effects on a diesel engine by antioxidant additives blend with Calophyllum inophyllum biodiesel. The results showed that $\mathrm{NO}_{\mathrm{x}}$ emissions reduced by $12.6 \%$ for Ethanox blended with biodiesel, and $21 \%$ for BHT blended with biodiesel but slightly more emissions of $\mathrm{CO}, \mathrm{HC}$, and smoke contrasted with biodiesel.

Velmurugan et al. [24] studied the influence of PHC, DEA, and TBHQ antioxidant additives added to mango seed biodiesel on CI engine. The performance results reported that the same BTHE was obtained with and without antioxidants in biodiesel. The obtained emission results were $\mathrm{NO}_{\mathrm{x}}$ emissions reduced by $18.19 \%$ by adding additives in the B20 fuel blend, and 7.94\% of CO, smoke, and $6.94 \%$ of HC emissions increase when correlated with conventional diesel. Kyunghyum [25] studied the impact on oxidation stability and emissions on the CI engine by use of TBHQ, BHT, PrG, a-tocopherol, and BHA antioxidants blended with biodiesel. The results reported that TBHQ antioxidants blended with biodiesel showed better oxidation stability when compared with other blends. There was no difference in $\mathrm{NO}_{\mathrm{x}}$ emissions with and without additives added in biodiesel. Kalam et al. [26] carried out CI engine experiments using 4-Nonyl phenoxy acetic acid (NPAA) antioxidant additive blended with palm biodiesel. The obtained results reduced both $\mathrm{NO}_{\mathrm{x}}$ and $\mathrm{CO}$ emissions when compared with diesel.

\section{OBJECTIVE OF CURRENT STUDY}

The past studies reported that biodiesel's major problems as fuel on diesel engines were low $\mathrm{CV}$ and increased $\mathrm{NO}_{\mathrm{x}}$ emissions. Previous literature said that nanoparticles added to biodiesel as fuel on diesel engines would improve engine performance and decrease exhaust emissions expect carbon dioxide. The literature review reported that antioxidants added to biodiesel as fuel on diesel engines would slightly improve performance and reduce $\mathrm{NO}_{\mathrm{x}}$ emissions but slightly increase other emissions. The past studies reported some of the disadvantages of biodiesel blended with antioxidants and nanoparticles individually. A few studies discussed the effects of multiple additives blended with biodiesel on a diesel engine. The current investigation compares the impact on a diesel engine using both NPPD antioxidant and $\mathrm{TiO}_{2}$ nanoparticles blended with Palm biodiesel blends contrasted with diesel.

\section{MATERIALS AND METHODS}

Palm oil was purchased from Super India Enterprises, Jaipur, India. Diesel fuel was bought from the local city. NPPD antioxidant was obtained from Loba Chemie Pvt. Ltd, Mumbai. Table 1 illustrated the specifications of NPPD antioxidant. From nano research lab the $\mathrm{TiO}_{2}$ nanoparticles
Table 1. Properties of antioxidant

\begin{tabular}{lc}
\hline Antioxidant name & $\begin{array}{c}\text { N-phenyl-1,4- } \\
\text { phenylenediamine(NPPD) }\end{array}$ \\
\hline Molecular weight & 184.240 \\
Chemical formula & $\mathrm{C}_{12} \mathrm{H}_{12} \mathrm{~N}_{2}$ \\
Density & Not specified \\
Melting point & $68^{\circ} \mathrm{C}$ \\
Flash point & $193^{\circ} \mathrm{C}$ \\
\hline
\end{tabular}

Table 2. Properties of nanoparticles.

\begin{tabular}{lc}
\hline Molecular formula & $\mathrm{TiO}_{2}$ \\
\hline Appearance & White solid \\
Density $\left(\mathrm{g} / \mathrm{cm}^{3}\right)$ & 4.23 \\
Molecular weight $(\mathrm{g} / \mathrm{mol})$ & 79.87 \\
Melting point $(\mathrm{K})$ & 2,116 \\
Boiling point $(\mathrm{K})$ & 3,245 \\
Solubility in water & insoluble \\
Ti content (Based on Metal) & $99.6 \%$ \\
Chemical composition Titanium & $59.33 \%$ \\
Oxygen & $40.55 \%$ \\
\hline
\end{tabular}

with an average size of less than $100 \mathrm{~nm}$ were purchased. Nanoparticles specifications are showed in Table 2.

\subsection{Preparation of fuel blends}

Raw palm oil is converted to palm oil methyl ester (POME) using an alkaline transesterification process. Methoxide solution was made by a $1 \%$ volume of sodium hydroxide dissolved in $25 \%$ volume of methanol with a magnetic stirrer. Raw palm oil was heated up to $65{ }^{\circ} \mathrm{C}$ using an ultrasonicator, then methoxide solution was poured into it. The mixture was stirred and maintained for $1 \mathrm{~h}$ and then the oil was separated into a separating funnel. After $24 \mathrm{~h}$, oil settled down with two layers due to gravity in separating funnel. The upper part of the separating funnel was crude POME, and the lower part of the separating funnel was glycerol. Now the crude POME was separated with glycerol and later washed with hot distilled water. These crude POME were heated up to $100{ }^{\circ} \mathrm{C}$ because it removes the water content of oil, and the oil thus obtained was clean POME. The use of an ultrasonicator prepared different test fuel blends. Table 3 illustrates the different types of fuel

Table 3. Types of blends with composition

\begin{tabular}{lc}
\hline Blend Name & Composition \\
\hline B0 & $100 \%$ Diesel $+0 \%$ Biodiesel \\
B20 & $80 \%$ Diesel $+20 \%$ Biodiesel \\
B20AO & $80 \%$ Diesel $+20 \%$ Biodiesel $+1,500$ \\
& PPM NPPD antioxidant \\
B20TO & $80 \%$ Diesel $+20 \%$ Biodiesel $+60 \mathrm{PPM}$ \\
B20AOTO & $\mathrm{TiO}_{2}$ nanoparticles \\
& $80 \%$ Diesel $+20 \%$ Biodiesel $+1,500$ \\
& PPM NPPD antioxidant $+60 \mathrm{PPM}$ \\
$\mathrm{TiO}_{2}$ nanoparticles
\end{tabular}


Table 4. Properties of test fuels

\begin{tabular}{lccccccc}
\hline & & & Palm Oil Methyl Ester & & & \\
Properties & Diesel & Raw palm oil & B100 & B20 Fuel & B20 AO & B20TO & B20 AOTO \\
\hline Density $\left(\mathrm{kg} / \mathrm{m}^{3}\right)$ & 820 & $906-911$ & 870 & 840 & 839.5 & 839 & 832 \\
Viscosity $\left(\mathrm{mm}^{2} / \mathrm{s}\right)$ & 3.40 & 37.60 & 4.40 & 3.50 & 3.39 & 3.3 & 2.75 \\
Flash point $(\mathrm{K})$ & 321 & 496 & 369 & 341 & 344 & 342 & 333 \\
Fire point $(\mathrm{K})$ & 327 & 515 & 399 & 371 & 376 & 374 & 361 \\
Cetane Number & 48 & $40-44$ & 54.2 & 52 & 51.5 & 51.85 & 59 \\
Calorific value $(\mathrm{MJ} / \mathrm{kg})$ & 43.2 & 36.31 & 39.8 & 41.4 & 41.5 & 41.9 & 42.9 \\
\hline
\end{tabular}

blends with composition. ASTM standards were used to find out the properties of the different blends. Table 4 shows the properties of different fuel blends.

\subsection{Experimental setup}

Figure 1 illustrated the experimental test rig. Single cylinder variable VCR diesel engine with a hydraulic dynamometer was used to perform experiments using different blends. Table 5 shows the specifications of the test rig. DAS consists of the various fuel measurement, digital load sensors, cylinder pressure, crank angle location sensors and airflow rate incorporated with engine setup. Engine Soft software is used to measure the performance parameters of a diesel engine. Multi-gas analyzer was used to measure the exhaust emissions of $\mathrm{CO}, \mathrm{HC}, \mathrm{O}_{2}, \mathrm{CO}_{2}$, and $\mathrm{NO}_{\mathrm{x}}$ emissions. Table 6 shows the range and resolution of different gasses of the multi-gas analyzer. Table 7 illustrates the percentage of uncertainty and accuracy of the measurements.

\section{RESULTS AND DISCUSSION}

The current research work illustrates the effects on CI engine by adding NPPD antioxidant and titanium oxide $\left(\mathrm{TiO}_{2}\right)$ nanoparticles additives blended with biodiesel. The test were conducted five times in the exhaust gas analyzer to confirm the emission data values.

\subsection{Engine performance}

BSFC refers to the fuel efficiency of any engine that burns fuel and produces a requirement of power. It is completely dependent on the test fuel blend properties, and the fuel

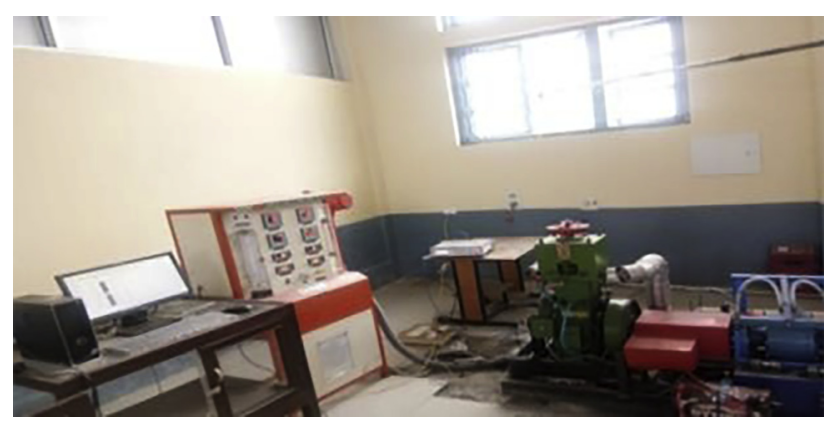

Fig. 1. Experimental test rig property of calorific value is majorly affecting the BSFC of the CI engine. BSFC of tested blends varies in load, as illustrated in Fig. 2. BSFC of fuel increase with the increase

Table 5. Specifications of test rig

\begin{tabular}{lc}
\hline Parameters & Specifications \\
\hline Make & TECH-ED \\
Model & Four stroke single cylinder water \\
& cooled VCR diesel engine \\
Basic engine & Kirloskar \\
Rated power & up to $4 \mathrm{KW}$ \\
Bore & $80 \mathrm{~mm}$ \\
Stroke & $110 \mathrm{~mm}$ \\
Connecting rod length & $234 \mathrm{~mm}$ \\
Capacity & $552 \mathrm{cc}$ \\
Compression ratio & $12: 1$ to $20: 1$ \\
Speed & $1,500 \mathrm{rpm}$ \\
Dynamometer & Hydraulic dynamometer \\
Piezo electric pressure & 0 to 5,000 psi \\
sensor & \\
\hline
\end{tabular}

Table 6. Specifications of range and resolution of the exhaust gas emissions

\begin{tabular}{lcc}
\hline Measurement & Range & Resolution \\
\hline $\mathrm{NO}_{\mathrm{x}}$ & $0-5,000 \mathrm{ppm}$ & $1 \mathrm{ppm}$ vol \\
$\mathrm{CO}_{2}$ & $0-20 \% \mathrm{vol}$ & $0.010 \% \mathrm{vol}$ \\
$\mathrm{O}_{2}$ & $0-25 \% \mathrm{vol}$ & $0.10 \% \mathrm{vol}$ \\
$\mathrm{CO}$ & $0-9.99 \% \mathrm{vol}$ & $0.001 \%$ vol \\
Engine RPM & $500-6,000 \mathrm{rpm}$ & $1 \mathrm{rpm}$ \\
$\mathrm{HC}$ (propane) & $0-15,000 \mathrm{ppm}$ & $1 \mathrm{ppm}$ \\
Lambda & $0.2000-2.000 \%$ & 0.0010 \\
Oil Temperature & $0-150{ }^{\circ} \mathrm{C}$ & $1{ }^{\circ} \mathrm{C}$ \\
\hline
\end{tabular}

Table 7. The percentage of uncertainty and accuracy for the measurements

\begin{tabular}{lcc}
\hline Measurements & Percentage uncertainty & Accuracy \\
\hline Temperatures & \pm 0.1 & $\pm 1^{\circ} \mathrm{C}$ \\
Engine speed & \pm 0.2 & $\pm 2 \mathrm{rpm}$ \\
Hydrocarbon & \pm 0.2 & $\pm 10 \mathrm{ppm}$ \\
Carbon monoxide & \pm 0.2 & $\pm 0.02 \%$ \\
Nitrogen oxides & \pm 0.2 & $\pm 15 \mathrm{ppm}$ \\
Crank angle encoder & \pm 0.2 & $\pm 0.5 \mathrm{CA}$ \\
Burette fuel measurement & \pm 1.5 & $\pm 2 \mathrm{CC}$ \\
Load & \pm 0.2 & $\pm 1 \mathrm{~N}$ \\
\hline
\end{tabular}




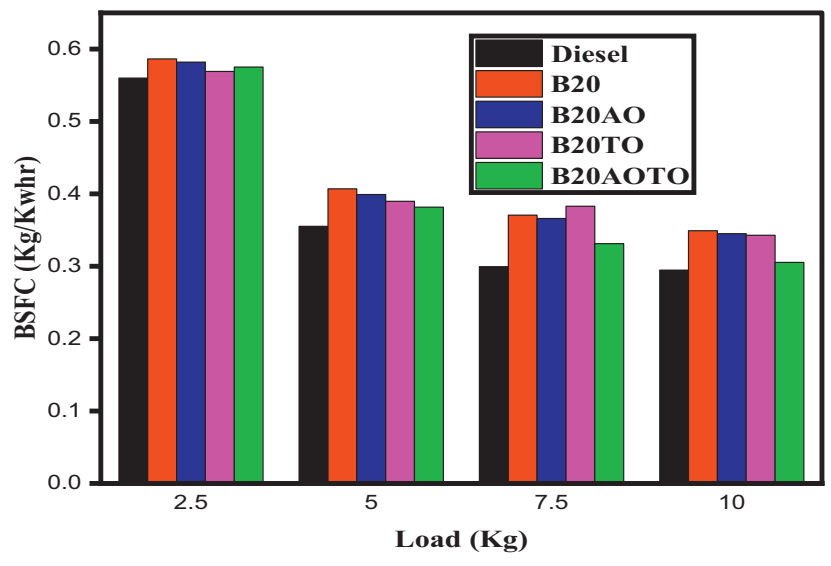

Fig. 2. Brake Specific Fuel Consumption (BSFC) vs. load

of load on a diesel engine in all cases. It was found that the BSFC of B20 blend was raised when compared with diesel because pure biodiesel produces $5-10 \%$ less CV than diesel fuel. Though biodiesel consists of $20 \%$ of diesel, it generates $2 \%$ of the low CV of diesel. The lower BSFC value was obtained by using the B20AOTO blend as contrasted to B20 blends and farther it showed the same BSFC value at full load compared with diesel. Nanoparticles blended with biodiesel improved rapid evaporation, better air-fuel mixing, high surface-to-volume ratio, high $\mathrm{CV}$, and atomization, resulting in lower BSFC correlated to biodiesel. The friction step down the quality of amine antioxidants is another factor of additives for lower BSFC value.

BTHE shows how efficiently the energy of fuel converted into mechanical work. BTHE appeared as a function of BSFC and it shows the reverse trends according to BSFC trends. BTHE of biodiesel fuel showed less compared to diesel, as shown in Fig. 3. The lower BTHE value was obtained by the use of the B20AOTO blend as contrasted to B20 tested blends and farther it showed the same BTHE value when compared with diesel. BTHE of B20 blends was enhanced somewhat by adding nanoparticles to biodiesel. It is due to the biodiesel blended with nanoparticles, which comprises the high $\mathrm{CV}$ and high surface area to volume ratio hence leading to better combustion. Also, the addition of nano additives causes improved thermal stability property, which acts as an oxidation catalyst that leads to enhanced combustion, resulting in higher BTHE. Friction reduction properties of antioxidants cause to increase BTHE of a CI engine at part loads, as shown in Fig. 3. At full load condition, BTHE of a CI engine decreases by antioxidants blended with biodiesel. The reasons for reducing BTHE was ignition delay and heat release rate owing to slightly reducing reaction rate because of the free radicals reduced by antioxidants.

EGT of fuel was influenced by the engine loading and dynamics of the exhaust system. Figure 4 shows that EGT of tested blends varies with load. EGT of tested blends increases by increasing the load on the CI engine. Figure 4 shows the lower EGT of biodiesel as contrasted with diesel. The primary reason for these is the high calorific value of

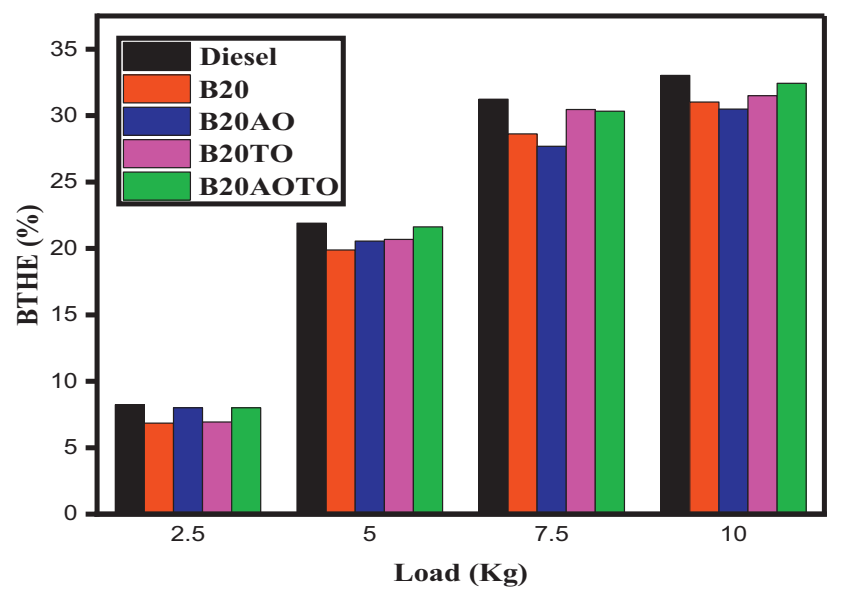

Fig. 3. Brake Thermal Efficiency (BTHE) vs. load

diesel fuel contributing to higher EGT, which indicates the loss of heat energy through the exhaust. From Fig. 4, EGT of B20 blends with antioxidants decreased and increased by the use of B20 blend with nanoparticles compared with diesel. The blend B20AOTO yielded lower EGT compared to other blends at high load. Nanoparticles blended with biodiesel exhibit higher EGT compared to different biodiesel blends because of nanoparticles' ability to improve the combustion and thus improve the BTHE of the engine. Antioxidants blended with biodiesel decrease EGT because antioxidants act as a deterrent in the fuel reaction.

\subsection{Emission results}

The reasons for generating $\mathrm{CO}$ emissions of a diesel engine were low flame temperature, lower injection pressure, and too rich fuel-air ratio. Higher $\mathrm{CO}$ emissions may cause increased power losses of a diesel engine. Different factors for producing $\mathrm{CO}$ emissions are too high (or) too lean equivalence ratio and insufficient residence time. The $\mathrm{CO}$ emissions can be reduced by blending biodiesel with diesel fuel, which increases the oxygen concentration during the combustion, resulting in increased $\mathrm{CO}$ oxidation. The $\mathrm{CO}$

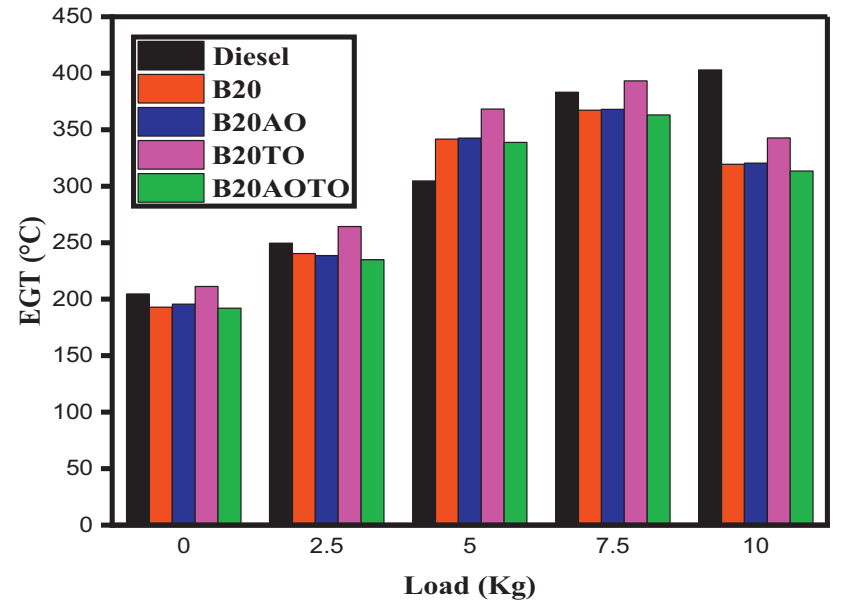

Fig. 4. Exhaust Gas Temperature (EGT) vs. load 


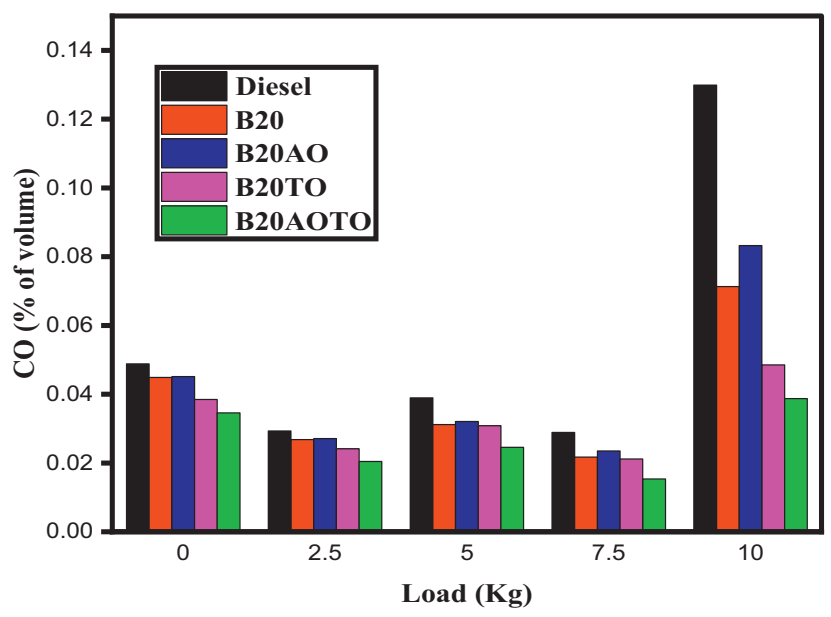

Fig. 5. Carbon Monoxide (CO) vs. load

emissions of tested blends vary in load, as illustrated in Fig. 5. Diesel engines release lower levels of CO emissions, and it further reduces by using biodiesel as a fuel. Biodiesel contains oxygen molecules in their chemical composition, so it promotes complete combustion, thus leading to diminishing $\mathrm{CO}$ emissions. The other factor of reduced $\mathrm{CO}$ emissions was high $\mathrm{CN}$ and oxygen $\left(\mathrm{O}_{2}\right)$ molecules in biodiesel that give complete combustion of fuel. B20AOTO blend generated low $\mathrm{CO}$ emissions when compared with other blends. Nanoparticles blended with biodiesel ensured to reduce $\mathrm{CO}$ emissions because it further increased the oxygen content of fuel blend, and it has advanced ignition characteristics resulting in catalytic activity. The $\mathrm{CO}$ emissions increased by adding antioxidants to biodiesel, as illustrated in Fig. 5. The primary reason for increasing CO emissions is due to incomplete combustion resulting from the addition of antioxidant additives.

The primary causes for the production of $\mathrm{HC}$ emissions are incomplete flame propagation, the composition of the too lean or rich mixture, low injection pressure, and lower charge temperature. Diesel engines emit $1 / 5^{\text {th }}$ lesser HC emissions as correlated to petrol engines due to lean equivalence ratio. The $\mathrm{HC}$ emissions from tested blends vary in load, as illustrated in Fig. 6. The HC emissions increase with the increase of load on CI engine in all cases. HC emissions reduced by biodiesel fuel because it contains oxygen molecules, which ensure complete combustion and also due to the high $\mathrm{CN}$ of biodiesel, which often comprises oxygen molecules that contribute to complete combustion. The B20AOTO blend produced low HC emissions when compared with other blends. Nanoparticles blended with biodiesel ensured to reduce $\mathrm{HC}$ emissions because it further increased the oxygen content of fuel blend, and high surface to volume ratio of nanoparticles. The $\mathrm{HC}$ emissions increased by adding antioxidants to biodiesel, as illustrated in Fig. 6. The primary reason for increasing $\mathrm{HC}$ emissions is due to the reduction of the formation of free radicals resulting from the addition of antioxidant additives.

The production of $\mathrm{NO}_{\mathrm{x}}$ emissions depends on volumetric efficiency, combustion duration, and high combustion

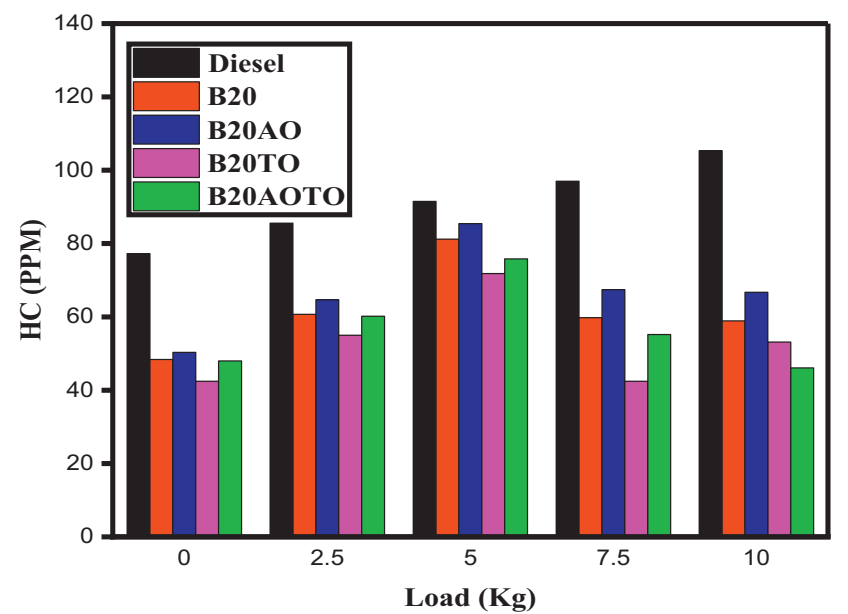

Fig. 6. Hydrocarbons (HC) vs. load

temperature for the high energy activation required for the reactions involved. Biodiesel combustion produces higher emissions of $\mathrm{NO}_{\mathrm{x}}$ than diesel due to its rich oxygen content, which causes the fuel-rich areas to respond to oxidation at high combustion temperatures, and it leads to the formation of $\mathrm{NO}_{\mathrm{x}}$ emissions. Figure 7, B20 fuel showed high $\mathrm{NO}_{\mathrm{x}}$ emissions when contrasted with diesel. The principle reason for increasing $\mathrm{NO}_{\mathrm{x}}$ emissions is biodiesel's molecular structure and the formation of $\mathrm{CH}$ radicals. Various theories explained that the increased $\mathrm{NO}_{\mathrm{x}}$ emissions are the advancement of fuel injection timing, the higher adiabatic flame temperature of biodiesel, more stoichiometric burning, larger spray droplet size, reduced radiation from soot particles, and fuel bound oxygen. The nitrogen molecule's strong triple covalent bond reacts to the free radical and ultimately forms $\mathrm{NO}_{\mathrm{x}}$ emission by successive chemical responses. However, the B20AOTO blend showed fewer $\mathrm{NO}_{\mathrm{x}}$ emissions contrasted with other blends. Metal oxide based nanoparticles blended with biodiesel as a fuel leading to complete combustion due to these acting as oxygen donating catalysts in the combustion chamber. During the combustion phase, the nanoparticles act as catalysts that reduce nitric oxide radicals to $\mathrm{N}_{2}$. Antioxidants act as a free radical quenching agent. Antioxidants blended with

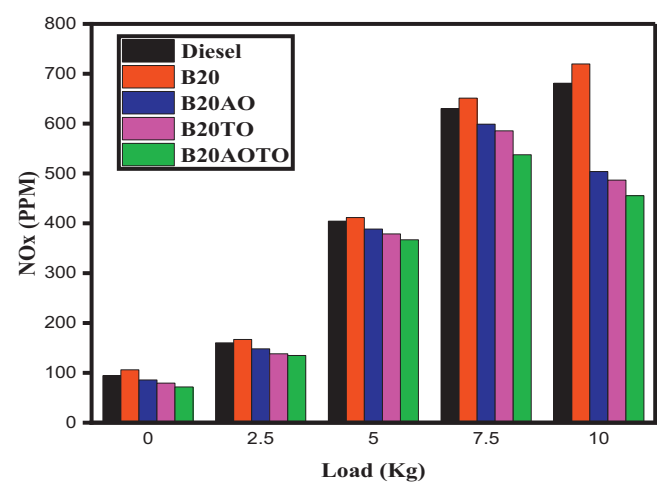

Fig. 7. Nitrogen Oxides $\left(\mathrm{NO}_{\mathrm{x}}\right)$ vs. load 
biodiesel produce fewer $\mathrm{NO}_{\mathrm{x}}$ emissions as a result of reducing the formation of free radicals.

\section{CONCLUSIONS}

Adding NPPD antioxidant and $\mathrm{TiO}_{2}$ nanoparticles to biodiesel blends improved the performance and emission parameters of the $\mathrm{CI}$ engine. Below are discussed the conclusions of the current research work.

B20 with additives showed lower BSFC when compared withB20 blends. Low BSFC was obtained with the use of the B20AOTO blend contrasted with other B20 blends. At maximum load, it was almost equal to diesel fuel. Biodiesel contributed high BTHE contrasted with diesel because of the high $\mathrm{CN}$ and $\mathrm{O}_{2}$ molecules present in biodiesel composition. Further, BTHE increases by blending antioxidants and nanoparticles with a B20 blend. At full load, B20AOTO showed high BTHE when contrasted with other blends. B20AOTO blend showed less EGT as compared to other tested fuel blends at high load. Nanoparticles blended with biodiesel exhibit higher EGT compared to different biodiesel blends because of nanoparticles' ability to improve the combustion and thus improve the BTHE of the engine. Antioxidants blended with biodiesel decrease EGT because antioxidants act as a deterrent in the fuel reaction.

B20AOTO blend showed low HC and CO emissions when compared with other blends. Biodiesel consists of high $\mathrm{CN}$, and the presence of oxygen molecules produces a complete combustion of fuel. $\mathrm{B} 20$ blends raise $\mathrm{NO}_{\mathrm{x}}$ emissions to $10 \%$ correlated to diesel. B20AOTO blend showed fewer $\mathrm{NO}_{\mathrm{x}}$ emissions contrasted with other blends. This investigation concluded that the B20AOTO blend showed optimum performance and emission parameters when compared with other blends.

\section{NOMENCLATURE}

\begin{tabular}{|c|c|}
\hline $\mathrm{Al}_{2} \mathrm{O}_{3}$ & aluminium oxide \\
\hline ASTM & $\begin{array}{l}\text { american society for testing and mate- } \\
\text { rials }\end{array}$ \\
\hline BHT & butylated hydroxytoluene \\
\hline BTHE & brake thermal efficiency \\
\hline BSFC & brake specific fuel consumption \\
\hline BHA & butylated hydroxyanisole \\
\hline B0 & $100 \%$ Diesel $+0 \%$ Biodiesel \\
\hline B20 & $80 \%$ Diesel $+20 \%$ Biodiesel \\
\hline B30 & $70 \%$ Diesel $+30 \%$ Biodiesel \\
\hline B50 & $50 \%$ Diesel $+50 \%$ Biodiesel \\
\hline $\mathrm{B} 20 \mathrm{AO}$ & $\begin{array}{l}80 \% \text { Diesel }+20 \% \text { Biodiesel }+1500 \\
\text { PPM NPPD antioxidant }\end{array}$ \\
\hline B20TO & $\begin{array}{l}80 \% \text { Diesel }+20 \% \text { Biodiesel }+60 \text { PPM } \\
\mathrm{TiO}_{2} \text { nanoparticles }\end{array}$ \\
\hline B20AOTO & $\begin{array}{l}80 \% \text { Diesel }+20 \% \text { Biodiesel }+1500 \\
\mathrm{PPM} \text { NPPD antioxidant }+60 \text { PPM } \\
\mathrm{TiO}_{2} \text { nanoparticles }\end{array}$ \\
\hline
\end{tabular}

\begin{tabular}{|c|c|}
\hline $\mathrm{CN}$ & cetane number \\
\hline $\mathrm{CV}$ & calorific value \\
\hline $\mathrm{CO}_{2}$ & carbon dioxide \\
\hline $\mathrm{CO}$ & carbon monoxide \\
\hline DI & direct injection \\
\hline CI & compression ignition \\
\hline DAS & data acquisition system \\
\hline DTBP & di-tert-butyl peroxide \\
\hline DEA & di-Ethyl Amine \\
\hline EGT & exhaust gas temperature \\
\hline GSBD & grape seed oil methyl ester \\
\hline GSBDZnO100 & $\begin{array}{l}\text { grape seed oil methyl ester }+100 \mathrm{ppm} \\
\text { zinc oxide nanoparticles }\end{array}$ \\
\hline $\mathrm{HC}$ & hydrocarbons \\
\hline HOME & honge oil methyl ester \\
\hline HOME50Graphene & $\begin{array}{l}\text { honge oil methyl ester }+50 \text { ppm gra- } \\
\text { phene }\end{array}$ \\
\hline JBD25A25CNT & $\begin{array}{l}\text { Jatropha biodiesel }+25 \text { ppm } \\
\text { aluminum oxide }+25 \text { ppm carbon } \\
\text { nanotubes }\end{array}$ \\
\hline $\mathrm{NO}_{\mathrm{x}}$ & nitrogen oxides \\
\hline NPPD & N-phenyl-1,4-phenylenediamine \\
\hline NPAA & 4-Nonyl phenoxy acetic acid \\
\hline $\mathrm{N}_{2}$ & nitrogen \\
\hline $\mathrm{nm}$ & nanometers \\
\hline $\mathrm{O}_{2}$ & oxygen \\
\hline PHC & pyridoxine hydro-chloride \\
\hline PPM & parts per million \\
\hline POME & palm oil methyl ester \\
\hline PrG & propyl gallate \\
\hline PM & particulate matter \\
\hline PPDA & P-Phenylenediamine \\
\hline $\mathrm{SO}_{2}$ & sulfur dioxide \\
\hline $\mathrm{TiO}_{2}$ & titanium oxide \\
\hline TBHQ & tert butyl hydro quinone \\
\hline VCR & variable compression ratio \\
\hline
\end{tabular}

\section{REFERENCES}

[1] V. B. Chaudhari, S. U. Patel, and D. S. Dhaval Sodha, "Performance \& emission of C.I engine using neem- biodiesel with additives,” Int. J. Scientific Res., vol. 3, no. 4, pp. 164-6, 2012.

[2] R. D. Misra and M. S. Murthy, "Blending of additives with biodiesels to improve the cold flow properties, combustion, and emission performance in a compression ignition engine-A review," Renew. Sustain. Energy Rev., vol. 15, no. 5, pp. 2413-22, 2011.

[3] A. H. Demirbas and I. Demirbas, "Importance of rural bioenergy for developing countries," Energy Convers. Manag., vol. 48, no. 8, pp. 2386-98, 2007.

[4] S. M. A. Rahman, H. H. Masjuki, M. A. Kalam, M. J. Abedin, A. Sanjid, and H. Sajjad, "Impact of idling on fuel consumption and exhaust emissions and available idle-reduction technologies for diesel vehicles - A review," Energy Convers. Manag., vol. 74, pp. $171-82,2013$ 
[5] A. M. Ashraful, H. H. Masjuki, M. A. Kalam, I. M. Rizwanul Fattah, S. Imtenan, S. A. Shahir, and H. M. Mobarak, "Production and comparison of fuel properties, engine performance, and emission characteristics of biodiesel from various non-edible vegetable oils: A review," Energy Convers. Manag., vol. 80, pp. 202-28, 2014.

[6] A. S. Silitonga, H. H. Masjuki, T. M. I. Mahlia, H. C. Ong, W. T. Chong, and M. H. Boosroh, "Overview properties of biodieseldiesel blends from the edible and non-edible feedstock," Renew. Sustain. Energy Rev., vol. 22, pp. 346-60, 2013.

[7] S. K. Hoekman, A. Broch, C. Robbins, E. Ceniceros, and M. Natarajan, "Review of biodiesel composition, properties, and specifications," Renew. Sustain. Energy Rev., vol. 16, no. 1, pp. 143-69, 2012.

[8] W. N. M. Wan Ghazali, R. Mamat, H. H. Masjuki, and G. Najafi, "Effects of biodiesel from different feedstocks on engine performance and emissions: a review," Renew. Sustain. Energy Rev., vol. 51, pp. 585-602, 2015.

[9] A. Bai, P. Jobbagy, F. Farkas, J. Popp, G. Grasselli, J. Szendrei, and P. Balogh, "Technical and environmental effects of biodiesel use in local public transport," Transport. Res. Part D: Transport and Environ., vol. 47, pp. 323-35, 2016.

[10] M. I. Mahmud and H. M. Cho, "A review on characteristics, advantages and limitations of palm oil biofuel," Int. J. Glob. Warming, vol. 14, no. 1, pp. 81-96, 2018.

[11] J. B. Hirkude and A. S. Pdalkar, "Performance and emission analysis of a compression ignition engine operated on waste fried oil methylesters," Appl. Energy, vol. 90, no. 1, pp. 68-72, 2012.

[12] Z. M. Hasib, J. Hossain, S. Biswas, and A. Islam, "Bio diesel from mustard oil: A Renewable alternative fuel for small diesel engines," Mod. Mech. Eng., vol. 1, no. 2, pp. 77-83, 2011.

[13] S. Simsek, "Effects of biodiesel obtained from Canola, sefflower oils and waste oils on the engine performance and exhaust emissions," Fuel, vol. 265, p. 117026, 2020.

[14] S. M. A. Rahman, H. H. Masjuki, M. A. Kalam, M. J. Abedin, A. Sanjid, and M. M. Rahman, "Assessing idling effects on a compression ignition engine fuelled with Jatropha and Palm biodiesel blends," Renew. Energy, vol. 68, pp. 644-50, 2014.

[15] J. S. Basha and R. B. Anand, "Performance and emission characteristics of a DI compression ignition engine using carbon nanotubes blended diesel," Int. J. Adv. Therm. Sci. Eng., vol. 1, no. 1, pp. 67-76, 2010.
[16] V. A. Bhagwat, C. Pawar, and N. R. Banapurmath, "Graphene nanoparticle-biodiesel blended diesel engine," Int. J. Eng. Res. Technol., vol. 4, no. 2, pp. 75-8, 2015.

[17] V. Praveena, M. L. J. Martin, and V. E. Geo, "Experimental characterization of $\mathrm{CI}$ engine performance, combustion and emission parameters using various metal oxide nanoemulsion of grapeseed oil methyl ester," J. Therm. Anal. Calorim., vol. 139, pp. 3441-56, 2020.

[18] A. I. El-Seesy, A. M. A. Attia, and H. M. El-Batsh, "The effect of Aluminum oxide nanoparticles addition with Jojoba methyl esterdiesel fuel blend on a diesel engine performance, combustion and emission characteristics," Fuel, vol. 224, pp. 147-66, 2018.

[19] V. Dhana Raju, P. S. Kishore, K. Nanthagopal, and B. Ashok, "An experimental study on the effect of nanoparticles with novel tamarind seed methyl ester for diesel engine applications," Energy Convers. Manag., vol. 164, pp. 655-66, 2018.

[20] M. M. Musthafa, T. A. Kumar, T. Mohanraj, and R. Chandramouli, "A comparative study on performance, combustion and emission characteristics of diesel engine fuelled by biodiesel blends with and without an additive," Fuel, vol. 225, pp. 343-8, 2018.

[21] S. Rajendran, "Effect of antioxidant additives on oxides of nitrogen (NOx) emission reduction from Annona biodiesel operated diesel engine," Renew. Energy, vol. 148, pp. 1321-6, 2020.

[22] C. Dueso, M. Munoz, F. Moreno, J. Arroyo, N. Gil-Lalaguna, A. Bautista, A. Gonzalo, and J. L. Sanchez, "Performance and emissions of a diesel engine using sunflower biodiesel with a renewable antioxidant additive from bio-oil," Fuel, vol. 234, pp. 276-85, 2018.

[23] B. Ashok, K. Nanthagopal, A. K. Jeevanantham, P. Bhowmick, D. Malhotra, and P. Agarwal, "An assessment of calophyllum inophyllum biodiesel fuelled diesel engine characteristics using novel antioxidant additives," Energy Convers. Manag., vol. 148, pp. 935-43, 2017.

[24] K. Velmurugan and A. P. Sathiyagnanam, "Impact of antioxidants on $\mathrm{NO}_{\mathrm{x}}$ emissions from a mango seed biodiesel powered di diesel engine," Alexandria Eng. J., vol. 55, no. 1, pp. 715-22, 2016.

[25] R. Kyunghyum, "The characteristics of performance and exhaust emissions of a diesel engine using a biodiesel with antioxidants," Bioresour. Technol., vol. 101, pp. S78-82, 2010.

[26] M. A. Kalam and H. H. Masjuki, "Testing palm biodiesel and NPAA additives to control $\mathrm{NO}_{\mathrm{x}}$ and $\mathrm{CO}$ while improving efficiency in diesel engines," Bio Mass and Bio Energy, vol. 32, pp. 1116-22, 2008. 